\title{
GENETIC CHARACTERIZATION OF Xylella fastidiosa ISOLATED FROM CITRUS AND COFFEE PLANTS
}

\author{
Vicente Savonitti Miranda ${ }^{*}$; Paulo Roberto Silva Farias ${ }^{1}$; Sérgio Rufo Roberto ${ }^{2}$; Pedro \\ Magalhães Lacava ${ }^{3}$ \\ ${ }^{1}$ UFRA - Instituto de Ciências Agrárias - Av. Presidente Tancredo Neves, 2501 - 66077-530 - Belém, PA - \\ Brasil. \\ ${ }^{2} U E L$ - Depto. de Agronomia - C.P. 6001 - 86051-990 - Londrina, PR - Brasil. \\ ${ }^{3}$ UNITAU - Estrada municipal Dr. José Luiz Cembranelli, 5000 - 12081-010 - Taubaté, SP - Brasil. \\ *Corresponding author <vicente.miranda@ufra.edu.br>
}

\begin{abstract}
The Citrus Variegated Chlorosis and the Coffee Leaf Scorch are some of the many destructive diseases caused by Xylella fastidiosa, a gram-negative bacterium limited to the xylem of affected plants. As its genetic characterization is still not well established, different isolates of $X$. fastidios $a$ from citrus and coffee were evaluated through RAPD (Random Amplified Polymorphic DNA) technique to characterize and classify these isolates based on similarity coefficients. Sixteen isolates of $X$. fastidiosa were used on this trial, obtained from citrus, coffee and almond. The genetic polymorphism evaluation was performed using six arbitrary 10-base primer pairs. It was possible to establish a dendogram in which the isolates were classified into five groups (A, B, C, D and E). A prevalence of citrus isolates in groups A and D was observed. In groups B and C, there was a prevalence of coffee isolates meanwhile the group D consisted of the almond isolate, solely.
\end{abstract}

Key words: RAPD, gram-negative bacterium, genetic divergence

\section{CARACTERIZAÇÃO GENÉTICA DE Xylella fastidiosa ISOLADA DE PLANTAS DE CITROS E CAFÉ}

\begin{abstract}
RESUMO: A Clorose Variegada dos Citros e a Requeima das Folhas do Cafeeiro são algumas das várias doenças destrutivas causadas pela Xylella fastidiosa, que é uma bactéria gram-negativa e limitada ao xilema de plantas afetadas. Como a sua caracterização genética ainda não está determinada, diferentes isolados da $X$. fastidiosa de citros e café foram avaliados pela técnica RAPD (Polimorfismo do DNA Amplificado ao Acaso) para caracterizar e classificar estes isolados com base em coeficientes de similaridade. Foram utilizados 16 isolados de $X$. fastidiosa provenientes de citros, café e amêndoa. A avaliação do polimorfismo genético foi realizada utilizando seis iniciadores randômicos de 10 pares de base. Foi possível estabelecer um dendograma no qual os isolados foram classificados em cinco grupos (A, B, C, D e E). Nos grupos A e D existe uma forte predominância de isolados de citros. Nos grupos B e C há predominância de isolados de café enquanto no grupo E ficou apenas o isolado de amêndoa.

Palavras-chave: RAPD, bactéria gram-negativa, divergência genética
\end{abstract}

\section{INTRODUCTION}

In the last 100 years, some fruit plants of economical importance mainly in North America were submitted to significative losses caused by Xylella fastidiosa (Wells et al., 1987), a xylem-limited gramnegative bacterium, which affects a large number of species, including mono and dicotyledon woody plants (Chagas et al., 1992).

In Brazil, this bacterium is the causal agent of the Citrus Variegated Chlorosis (CVC), Coffee Leaf Scorch (CLS) and Plum Leaf Scald (PLS) diseases. It was observed for the first time in the Sao Paulo and Minas Gerais states, in 1987 (Lee et al., 1993). At this moment, the CVC was found widespread over citrus orchards in São Paulo, Paraná (Leite \& Jacomino,
1993), Minas Gerais (Mizubuti et al., 1994), Rio de Janeiro (Lee et al., 1991; Rossetti \& De Negri, 1990), Goiás, Sergipe, Santa Catarina, Distrito Federal and Rio Grande do Sul states (Tubelis et al., 1993). The symptoms occur initially in a portion of the tree and then they spread very fast over the whole canopy. The branches located at the top of the tree die along time, the leaves fall and the fruit production is reduced one year after the tree has been infected (Lee et al., 1993).

The Coffee Leaf Scorch (CLS) was firstly reported in October of 1995 causing outbreaks in some regions of Sao Paulo state and south of Minas Gerais state (Paradela Filho et al., 1995). The causal agent was isolated and cultivated (Lima et al., 1996). At this mo- 
ment, the CLS was found widespread over coffee areas on Paraná, São Paulo, Minas Gerais, Espírito Santo, Bahia, Rio de Janeiro and Rondonia states in Brazil (Matiello et al., 1998). Small and yellow and light green colored leaves, mainly on the top of coffee trees, short branch nodes, reduction of tree growth and death of lateral branches are symptoms observed for this disease (Matiello et al., 1998).

The genetic characterization of $X$. fastidiosa has not yet been established. Considering the above mentioned aspects, the objective of this study was to characterize the isolates of citrus and coffee using the RAPD (Random Amplified Poliforfism DNA) technique, and to build a dendogram for these isolates based on their similarity degree.

\section{MATERIAL AND METHODS}

\section{Citrus and coffee plants used for isolation}

Six year-old trees showing symptoms of CVC and CLS from North, South, East, and West of the Sao Paulo and Paraná states (Brazil), from Missiones (Argentina) and California (USA) were used in this trial. Symptomatic mature leaves of 'Pera' and 'Valencia' orange trees and 'Mundo Novo' coffee were removed to obtain extracts from the vessel tissues. In this way, 16 isolates were obtained (Table 1) from citrus and coffee which were used for all trials, from 1998 to 2000.

\section{Growth medium}

The periwinkle medium (PW) was used for bacterial growth, and consisted of soy peptone $4.0 \mathrm{~g}$; hydrolyzed casein $1.0 \mathrm{~g} ; \mathrm{K}_{2} \mathrm{HPO}_{4}, 1.2 \mathrm{~g} ; \mathrm{KH}_{2} \mathrm{PO}_{4}, 1.0$ $\mathrm{g} ; \mathrm{MgSO}_{4} 7 \mathrm{H}_{2} \mathrm{O}, 0.4 \mathrm{~g}$; agar, $12.0 \mathrm{~g}$; hemine chloride $(0.1 \%), 10.0 \mathrm{~mL}$; phenol red $(0.2 \%), 10.0 \mathrm{~mL}$; distilled water, $920.0 \mathrm{~mL}$; bovine serum albumin (BSA) $(6.7 \%)$, $6.0 \mathrm{~g} / 60.0 \mathrm{~mL}$ and glutamine (8.0\%), $4.0 \quad \mathrm{~g} / 100.0$ $\mathrm{mL}$. The BSA and glutamine were diluted in water and then filtered $(0.45$ and $0.22 \mu \mathrm{m})$ before being added to the previously autoclaved medium.

\section{Bacteria isolation technique}

Leaves were placed on a slide glass and the petioles chopped. Then, petioles were sterilized using $70 \%$ ethanol during one min, washed three times in distilled water, exposed to $3 \%$ sodium hypochlorite during three min, and then washed three times in sterile distilled water (Lima et al., 1998).

For bacteria isolation, petioles were chopped into $2 \mathrm{~mm}$ sections, placed in a centrifuge tube $(15 \mathrm{~mL})$, adding $1 \mathrm{~mL}$ of PW liquid medium and centrifuged at $150 \mathrm{~g}$ during ten min at local temperature. Then, a fraction of $0.1 \mathrm{~mL}$ was removed from the supernatant and transferred to a glass tube containing $5.0 \mathrm{~mL}$ of $\mathrm{PW}$ medium.

\section{Xylella fastidiosa culture}

Cultures were made on PW medium using agar $(1.2 \%)$ or on liquid PW medium (pH 6.6) at $28^{\circ} \mathrm{C}$. A dilution series was performed $(1: 100,1: 1000$ and 1:10000) using bacteria cultured in liquid PW medium. Then, they were inoculated in solid PW medium to obtain isolated colonies. The colonies were removed and inoculated in PW liquid medium. This procedure was

Table 1 - Isolates of $X$. fastidiosa used on the trials.

\begin{tabular}{|c|c|c|c|c|c|}
\hline \multirow{2}{*}{ Code } & \multirow{2}{*}{ Location } & \multicolumn{2}{|c|}{ Coordinates } & \multirow{2}{*}{ Host } & \multirow{2}{*}{ Cultivar } \\
\hline & & Longitude & Latitude & & \\
\hline 1 & São Paulo, Cordeirópolis & $47^{\circ} 27^{\prime} 25^{\prime \prime}$ & $22^{\circ} 28^{\prime} 56^{\prime \prime}$ & Citrus & 'Pera' \\
\hline 2 & São Paulo, Jales & $50^{\circ} 32^{\prime} 46^{\prime \prime}$ & $20^{\circ} 16^{\prime} 09^{\prime \prime}$ & Citrus & 'Pera' \\
\hline 3 & São Paulo, Itapetininga & $48^{\circ} 03^{\prime} 12^{\prime \prime}$ & $23^{\circ} 35^{\prime} 31^{\prime \prime}$ & Citrus & 'Pera' \\
\hline 4 & São Paulo, São José Rio Preto & $49^{\circ} 22^{\prime} 47^{\prime \prime}$ & $20^{\circ} 49^{\prime} 12^{\prime \prime}$ & Citrus & 'Pera' \\
\hline 5 & São Paulo, Macaubal & $49^{\circ} 57^{\prime} 51^{\prime \prime}$ & $20^{\circ} 48^{\prime} 22^{\prime \prime}$ & Citrus & 'Pera' \\
\hline 6 & Missiones, Argentina & $55^{\circ} 40^{\prime} 12^{\prime \prime}$ & $27^{\circ} 47^{\prime} 23^{\prime \prime}$ & Citrus & 'Valencia' \\
\hline 7 & São Paulo, Matão & $48^{\circ} 21^{\prime} 58^{\prime \prime}$ & $21^{\circ} 36^{\prime} 13^{\prime \prime}$ & Coffee & 'Mundo Novo' \\
\hline 8 & Paraná, Londrina & $51^{\circ} 09^{\prime} 47^{\prime \prime}$ & $23^{\circ} 18^{\prime} 38^{\prime \prime}$ & Citrus & 'Pera' \\
\hline 9 & São Paulo, Taquaritinga & $48^{\circ} 30^{\prime} 18^{\prime \prime}$ & $21^{\circ} 24^{\prime} 23^{\prime \prime}$ & Citrus & 'Pera' \\
\hline 10 & São Paulo, Silvania & $48^{\circ} 19^{\prime} 31^{\prime \prime}$ & $21^{\circ} 20^{\prime} 14^{\prime \prime}$ & Coffee & 'Mundo Novo' \\
\hline 11 & São Paulo, Casa Branca & $47^{\circ} 05^{\prime} 12^{\prime \prime}$ & $21^{\circ} 46^{\prime} 27^{\prime \prime}$ & Coffee & 'Mundo Novo' \\
\hline 12 & São Paulo, Franca & $47^{\circ} 24^{\prime} 04^{\prime \prime}$ & $20^{\circ} 32^{\prime} 20^{\prime \prime}$ & Coffee & 'Mundo Novo' \\
\hline 13 & São Paulo, São Manuel & $48^{\circ} 34^{\prime} 15^{\prime \prime}$ & $22^{\circ} 43^{\prime} 53^{\prime \prime}$ & Coffee & 'Mundo Novo' \\
\hline 14 & São Paulo, Marília & $49^{\circ} 56^{\prime} 46^{\prime \prime}$ & $22^{\circ} 12^{\prime} 51^{\prime \prime}$ & Coffee & 'Mundo Novo' \\
\hline 15 & São Paulo, São José Rio Preto & $49^{\circ} 22^{\prime} 47^{\prime \prime}$ & $20^{\circ} 49^{\prime} 12^{\prime \prime}$ & Coffee & 'Mundo Novo' \\
\hline 16 & ATCC 35870 - California IUSA & $117^{\circ} 17^{\prime} 70^{\prime \prime}$ & $34^{\circ} 06^{\prime} 30^{\prime \prime}$ & Almond & --- \\
\hline
\end{tabular}

Sci. Agric. (Piracicaba, Braz.), v.64, n.5, p.482-485, September/October 2007 
repeated three times in order to obtain a 3-time cloned isolate.

\section{Extraction and amplification of DNA by the RAPD technique}

Genomic DNA extraction of bacteria isolates was performed as described by Costa et al. (2000).

The isolates of $X$. fastidiosa were analyzed using the RAPD technique to know the level of genetic similarity among them. The genomic DNA was amplified through the reaction using six 10-base primers (Pharmacia Biotec). Primers and annealing temperatures were: 5'GGTGCGGGAA $\left(34^{\circ} \mathrm{C}\right)$; 5' GTTTCGCTCC $\left(32^{\circ} \mathrm{C}\right) ; 5^{\prime}$ GTAGACCCGT $\left(32^{\circ} \mathrm{C}\right)$; 5'AAGAGCCCGT $\left(32^{\circ} \mathrm{C}\right)$; $5^{\prime}$ AACGCGCAAC $\left(32^{\circ} \mathrm{C}\right)$ and CCCGTCAGCA $\left(34^{\circ} \mathrm{C}\right)$. The PCR conditions were: $94^{\circ} \mathrm{C}$ during 5 min, followed by 43 cycles at $94^{\circ} \mathrm{C}$ for $1 \mathrm{~min}, 35^{\circ} \mathrm{C}$ for $2 \mathrm{~min}$, and $72^{\circ} \mathrm{C}$ for $2 \mathrm{~min}$. After then, an additional step of $72^{\circ} \mathrm{C}$ was performed during $7 \mathrm{~min}$. The band analyses were performed as conventionally by using $1 \%$ agarose gel electrophoresis (Figure 1).

\section{Data analysis}

Electrophoretic band patterns were compared to construct a binary matrix. The Jaccard - UPGMA (unweighted pair group method with arithmetic averages) method was used to calculate the genetic similarities using NTSYS-PC (Rohlf, 1989).

\section{RESULTS AND DISCUSSION}

Based on the dendogram (Figure 2), it was possible to classify the isolates into five groups: Group A (1, 4, 2 and 5), Group B (9, 12 and 14), Group C (7, 11,10 and 13), Group D (3, 6, 8 and 15) and Group E (16). Groups A and D presented a prevalence of citrus isolates; groups B and C of coffee isolates, and group E consisted only of the almond isolate. In relation to the genetic distance, in groups with the prevalence of

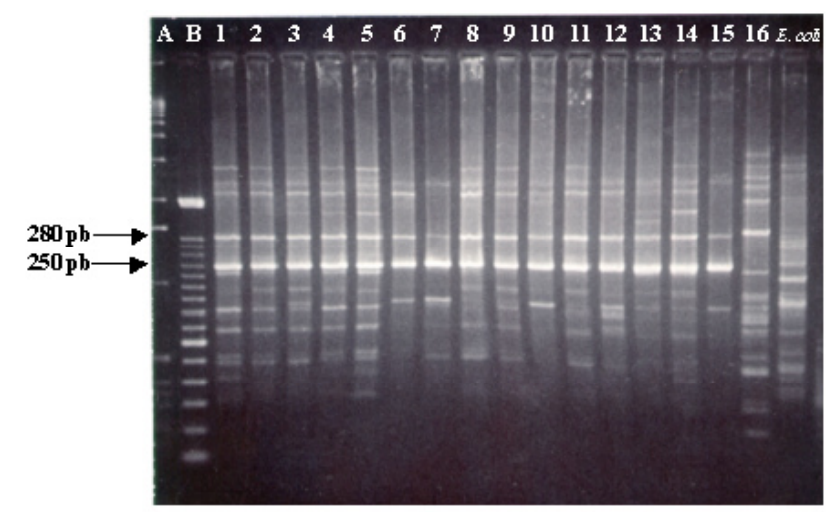

Figure 1 - RAPD of 16 isolates of $X$. fastidiosa using the primer 5 GGTGCGGGAA. E. coli profile was used as control. $\mathrm{A}$ and $\mathrm{B}$ are molecular standards.

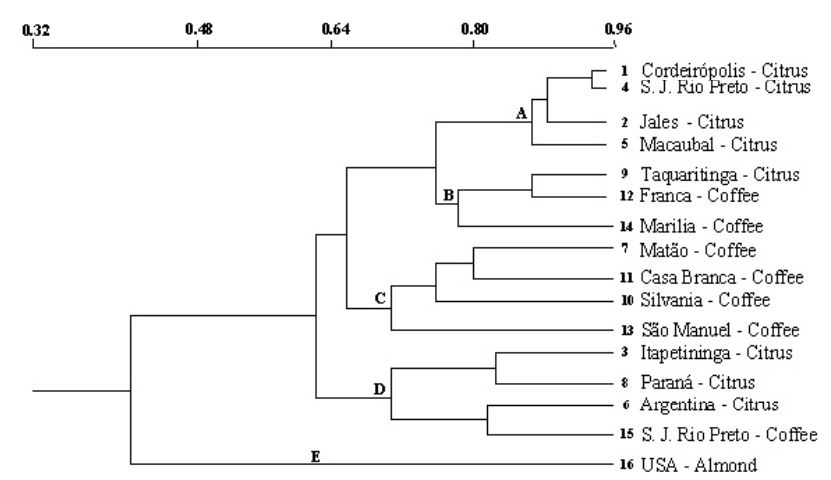

Figure 2 - Dendogram based on the genetic similarity among 16 $X$. fastidiosa isolates.

citrus isolates (A and D), this index ranged from 12 and $30 \%$, approximately. Groups with prevalence of coffee isolates (B and C) it ranged from 22 and $30 \%$ and the almond isolate (E) showed a genetic distance of $58 \%$ in relation to the other groups. Rosato et al. (1999) analyzed $42 X$. fastidiosa isolates of citrus, coffee, oleander and grapevine, and using eight distinct RAPD primers, classified the isolates of coffee and citrus into distinct groups.

Costa et al. (2000) classified citrus, coffee, plum and grapevine isolates into different groups using a distinct set of arbitrary primers in relation to those used in this research. These authors also observed a genetic divergence between isolates of citrus and coffee of $15 \%$. Lacava et al. (2001) analyzed 16 bacteria isolates from citrus, two from coffee and one from grapevine, and classified them into distinct groups. The genetic divergence between citrus and coffee isolates was less than 30\%. In another report, Qin et al. (2001) analyzed 78 isolates of $X$. fastidiosa from citrus, coffee, plum, grapevine, oak, almond and mulberry, classifying citrus and coffee isolates into different groups, with a genetic divergence of $20 \%$. These results are very similar to those here observed.

Despite the results here shown and those observed in other reports that grouped the citrus and coffee $X$. fastidiosa isolates into distinct groups, today it is widely known that coffee derived isolates are able to infect and produce symptoms on citrus plants, indicating those genetic divergences are not sufficient to hinder the cross inoculation between $X$. fastidiosa isolates.

\section{REFERENCES}

CHAGAS, C.M.; ROSSETTI, V.; BERETTA, M.J.G. Electron microscopy studies of xylem-limited bacterium in sweet orange affected with citrus chlorosis disease in Brazil. Journal of Phytopathology, v.134, p.306-312, 1992.

COSTA, P.I.; MIRANDA, V.S.; TEIXEIRA, D.C.; FRANCO, F.; HARTUNG, J. Strains of Xylella fastidiosa rapidly distinguished by arbitrarily primed PCR. Current Microbiology, v.40, p.279-282, 2000. 
LACAVA, P.T.; ARAÚJO, W.L.; MACCHERONI, W.; AZEVEDO, J.L. RAPD Profile and antibiotic susceptibility of Xylella fastidiosa Causal agent of citrus variegated chlorosis. Applied Microbiology, v.33, p.1-5, 2001.

LEE, R.F.; DERRICK, K.S.; BERETTA, M.J.G.; CHAGAS, C.M.; ROSSETTI, V. Citrus variegated chlorosis: a new destructive disease of citrus in Brazil. Citrus Industry, v.72, p.10-13, 1991.

LEE, R.F.; BERETTA, M.J.G.; HARTUNG, J.H.; HOOKER, M.E.; DERRICK, K.S. Citrus variegated chlorosis: confirmation of Xylella fastidiosa as the causal agent. Summa Phytopathologica, v.19, p.123-125, 1993.

LEITE, R.M.V.B.C.; JACOMINO, A.P. Ocorrência de clorose variegada dos citros no estado do Paraná. Summa Phytopathologica, v.19, p.35-36, 1993.

LIMA, J.E.O.; MIRANDO, V.S.; COUTINHO, A.; ROBERTO, S.R.; CARLOS, E.F. Distribuição de Xylella fastidiosa no cafeeiro, nas regiões cafeeiras e seu isolamento in vitro. Fitopatologia Brasileira, v.21, p.392-393, 1996.

LIMA, J.E.O.; MIRANDA, V.S.; HARTUNG, J.S.; BRLANSKY, R.H.; COUTINHO, A.; ROBERTO, S.R.; CARLOS, E.F. Coffee Leaf Scorch Bacterium: Axenic culture, pathogenicity, and comparison with Xylella fastidiosa of citrus. Plant Disease, v.82, p.94-97, 1998.

MATIELLO, J.B.; ALMEIDA, S.R.; GARCIA, A.W.R.; MIGUEL, A.E.; PERINE, J.A.; RAUJO, M.; MIRANDA, V.S.; MANFIO, G.P. Survey of occurrences of the "Amarelinho" in coffee plantation regions of Brazil and the first confirmation of "Conilon" in coffee trees. In: CONGRESSO BRASILEIRO DE CAFEICULTURA, 24., Poços de Caldas, 1998. Resumos. Poços de Caldas, 1998. p.17.

MIZUBUTI, E.S.G.; MATSUOKA, K.; PARIZZI, P. Associação de bactéria do tipo Xylella fastidiosa em laranjeiras com sintomas de clorose variegada na região da Zona da Mata de Minas Gerais. Fitopatologia Brasileira, v.19, p.241-244, 1994.

PARADELA FILHO, O.; SUGIMORI, M.H.; RIBEIRO, I.J. Primeira constatação em cafeeiro da Xylella fastidiosa causadora da clorose variegada dos citros. Laranja, v.16, p.127-134, 1995.
QIN, X.; MIRANDA, V.S.; MACHADO, M.A.; LEMOS, E.M.G.; HARTUNG, J. An Evaluation of the genetic diversity of Xylella fastidiosa isolated from citrus and coffee. Phytopathology, v.91, p.599-605, 2001.

ROHLF, E.J. NTSYS-PC. Numerical Taxonomy and Multivariate Analysis System. version 1.50. New York: Exeter, 1989.

ROSATO, Y.B.; NETO, J.R.; MIRANDA, V.S.; CARLOS, E.F.; MANFIO, G.P. Diversity of a Xylella fastidiosa population isolation from Citrus sinensis affected by citrus variegated chlorosis in Brazil. Systematic Applied Microbiology, v.21, p.583-598,1999.

ROSSETTI, V.; DE NEGRI, J.D. Clorose variegada dos citros. Laranja, v.11, p.1-14, 1990.

TUBELIS, A.; RODRIGUES NETO, J.; BERETTA, M.J.G. Primeira constatação da anomalia clorose variegada dos citros (CVC) no estado de Goiás. Summa Phytopathologica, v.19, p.46-47, 1993.

WELLS, J.M.; RAJU, B.C.; JUNG, H.Y.; WEISBURG, W.G.; MANDELCO-PAUL, L.; BRENNER, D.J. Xylella fastidiosa gen nov., sp.nov. gram negative, xylem limited fastidious plant bacteria related to Xanthomonas spp. International Journal of Systematic Bacteriology, v.37, p.136-143, 1987.

Received February 24, 2006

Accepted March 23, 2007 